\title{
Modelowanie indeksu cen nieruchomości mieszkaniowych w Polsce
}

\author{
Rafat Zbyrowski*
}

Celem autora artykutu jest próba opisania zależności pomiędzy poziomem cen na rynku nieruchomości mieszkaniowych, a zdolnościa kredytowa gospodarstw domowych w Polsce. Wstepnie rozpatrywana relacja przetestowana została w oparciu o procedure Engle-Grangera, a nastęnie potwierdzona przez model VAR i procedure Johansena. Czéść empiryczna opracowania pozwala scharakteryzować bliżej rodzaj związu dtugookresowego wraz z uwzględnieniem opóźnień właściwych dla analizowanego fragmentu rynku obrotu nieruchomościami. Badane zmienne należy uznać za kluczowe dla funkcjonowania rynku nieruchomości w Polsce. W analizie wykorzystano dane od potowy roku 2010 do 2014.

Słowa kluczowe: modelowanie wielorównaniowe, VAR, rynek nieruchomości, nieruchomości mieszkaniowe.

Nadesłany: 30.11.2016 | Zaakceptowany do druku: 28.12.2016

\section{Modelling for the Index of Residential Property Prices in Poland}

The main purpose of this article is to describe a dependence between prices of flats and index of creditworthiness in Poland. In the empirical part of this paper, the author tests mentioned relations according to Engle-Granger's procedure. Moreover, the long time relation was verified by Johansen's procedure and a VAR model. This case leads to the examination and estimation cointegration with testing lags between very important variables on the real estate market in Poland. The database used in the research contains monthly observations from the middle of 2010 to the begining of 2014.

Keywords: econometric modeling, VAR, real estate, residential real estate.

Submitted: 30.11.2016 | Accepted: 28.12.2016

JEL: G50, R30, R3

\footnotetext{
Rafał Zbyrowski - dr, Zakład Badań Operacyjnych Zarządzania, Wydział Zarządzania Uniwersytetu Warszawskiego.

Adres do korespondencji: Zakład Badań Operacyjnych Zarządzania, Wydział Zarządzania, Uniwersytet Warszawski, ul. Szturmowa 1/3, 02-678 Warszawa; e-mail: Rzbyrowski@wz.uw.edu.pl.
} 


\section{Wprowadzenie}

Aktywizacja programów rządowych związanych z dziedziną wspierania budownictwa mieszkaniowego w Polsce jest prowadzona od lat 90. Przechodzące już dawno w zapomnienie ulgi podatkowe zastąpione zostały przez znacznie mniej skuteczne programy „Rodzina na swoim”, a nasteppnie „Mieszkanie dla młodych”. Przez ostatnie 25 lat rynek nieruchomości w Polsce przechodził więc burzliwe zmiany o charakterze ekonomicznym i prawnym. Systematycznie następowało także uwalnianie tego rynku od wpływu szeroko zakrojonych kampanii rządowych mających na celu aktywizacje sektora mieszkaniowego na rzecz zwiększonej roli oddziaływania zmiennych makroekonomicznych, wśród których szczególną rolę odgrywają czynniki kształtujące zdolność kredytową gospodarstw domowych. Zdolność kredytowa jest zależna od wielu determinant, takich jak: dochód, okres kredytowania, waluta kredytu, stopa procentowa czy liczba członków stanowiących gospodarstwo domowe. Oczywiście najważniejszy jest dochód kredytobiorcy. Srednie wynagrodzenia w latach 2005-2013 wzrosły o $53,5 \%$, natomiast inflacja w tym okresie wyniosła 45,45\%, co świadczy, że realny dochód wzrósł o około $8 \%$. Zatem w ujęciu teoretycznym zdolność kredytowa powinna wzrosnąć (www.bankier.pl). Tak się niestety nie stało, ponieważ w okresie 12.2007-12.2013 zdolność kredytowa spadła o $15 \%$ (rysunek 1), czyli realny wzrost wynagrodzeń nie spowodował wzrostu zdolności kredytowej kupujących mieszkania. Istotnym czynnikiem decydującym o zdolności kredytowej jest również oprocentowanie kredytu. Zależy ono od wskaźnika WIBOR 3M dla kredytu w PLN (obecnie w rzadkich przypadkach od jego odpowiednika np. EURIBOR 3M dla waluty euro). Wskaźnik ten jest pochodny względem stopy inflacji. W latach 2005-2012 WIBOR $3 \mathrm{M}$ wynosił ok. $5 \%$, uzyskując rekordowa wartość $6,41 \%$ w roku 2008 , w którym na świecie trwał już kryzys, powoli docierając do Polski. W roku 2013 WIBOR 3M spadł o 76\% w stosunku do roku 2012. Obecnie jego wartość na poziomie $1,7 \%$ jest najniższa w historii (www.bankier. pl). Według danych firmy Home Broker (rysunek 1) indeks zdolności kredytowej dla 3-osobowej rodziny $\mathrm{z}$ dochodem netto na poziomie 5000 zł wzrósł w okresie od grudnia 2012 do kwietnia 2014 o 10,6\%. Zatem przeciętna badana rodzina mogła otrzymać średnio 387000 zł kredytu w kwietniu 2014 roku zamiast 350000 zl, możliwego do wzięcia kredytu w grudniu 2012 roku.

Wzrost zdolności kredytowej powoduje wzrost popytu, a w konsekwencji wzrost cen nieruchomości. Powyższa zależność ekonomiczna uwidacznia się częściowo na wykresach szeregów czasowych (rysunek 1), w kontekście których rodzą się następujące pytania: czy zależność pomiędzy poziomem cen na rynku nieruchomości mieszkaniowych i średnią zdolnością kredytową w Pol-

Rysunek 1. Poziom cen nieruchomości na tle przeciętnej zdolności kredytowej

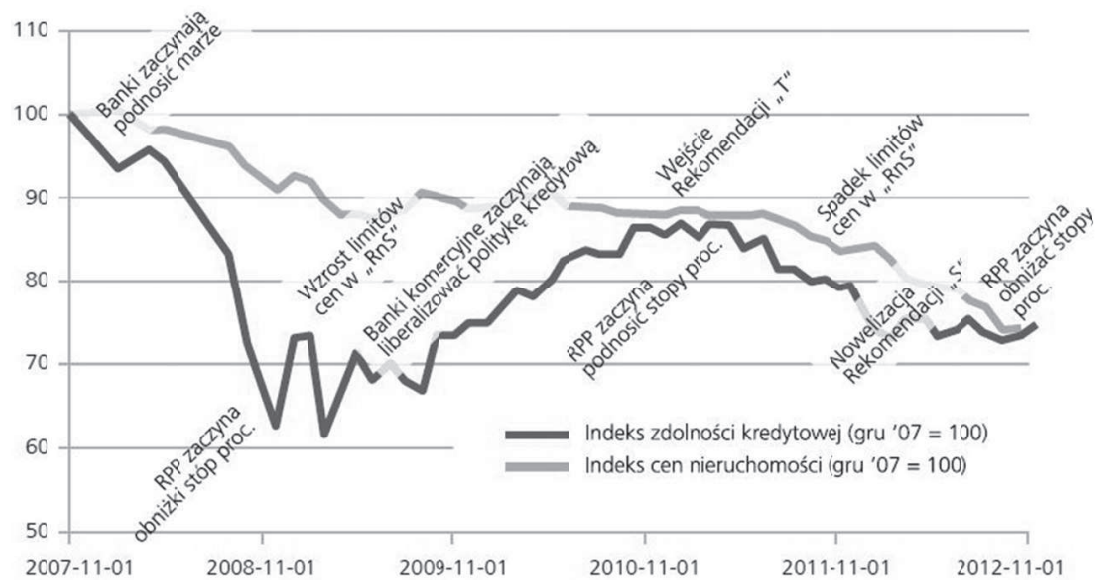

Źródło: www.egospodarka.pl, Rynek mieszkaniowy 2013 (29.12.2012).

Wydział Zarządzania UW DOI 10.7172/1733-9758.2016.22.8 
sce ma charakter długookresowy? oraz Jaka jest rzeczywista siła tej zależności?

$\mathrm{Na}$ powyższe pytania autor spróbuje udzielić odpowiedzi, opierając się na analizie kointegracji przeprowadzonej w ramach procedury Engle-Grangera i Johansena.

\section{Poziom cen nieruchomości na tle przeciętnej zdolności kredytowej}

Lata od 2008 do 2012 uważane są za okres kryzysowy w gospodarce zarówno polskiej, jak i światowej. Na rysunku 1 przestawiono, w jakim tempie spadała zdolność kredytowa konsumentów i jaki miało to wpływ na ceny nieruchomości w Polsce. Jak widać, wiele tendencji widocznych na rynku było związanych $\mathrm{z}$ działaniami banków i instytucji rządowych.

Obserwowana w latach 2008-2012 korekta cen mieszkań postępowała w różnych okresach ze zmienną dynamiką. W okresie od stycznia 2008 roku do połowy 2009 roku ceny mieszkań szybko spadały. Przyczyną tego była ograniczona akcja kredytowa spowodowana podniesieniem przez banki marż kredytowych, spadkiem zdolności kredytowej konsumentów, wzrostem liczby negatywnych decyzji, a przede wszystkim ograniczeniem kredytów walutowych zwłaszcza w CHF. W kolejnych miesiącach na rynek kredytów stopniowo zaczęły oddziaływać obniżki stóp procentowych, co zmniejszało koszt finansowania. Znaczenie miało też podniesienie limitów cenowych, kwalifikujących nawet stosunkowo drogie mieszkania do programu dopłat w programie Rodzina na swoim. W latach 2010 i 2011 nastapiła stabilizacja cen nieruchomości mieszkaniowych pomimo dynamicznie rosnącej ich podaży na rynku pierwotnym, spowodowana głównie liberalizacją polityki kredytowej banków komercyjnych. Niestety na początku 2011 roku pojawiły się podwyżki stóp procentowych i dodatkowo nadzór bankowy zaostrzył wymagania dotyczące dostępności kredytów. Według nowych regulacji Komisji Nadzoru Finansowego wysokość rat kredytowych nie mogła przekroczyć $50 \%$ dochodów netto dla osób zarabiających poniżej średniej krajowej i $65 \%$ dochodów dla pozostałej grupy. Konsekwencją tego był stopniowy spadek siły nabywczej na rynku nieruchomości. Ograniczeniem dla nabywców było też zmniejszenie od sierpnia 2011 roku dostępności programu Rodzina na swoim. Od tego momentu określenie w większości miast znacznie niższych limitów cen kwalifikujących mieszkania do dopłat w programie zwiększyło przecenę i konkurencję między podażową stroną rynku. Na początku 2012 roku wprowadzono w życie przepisy znowelizowanej rekomendacji „S”, co ograniczyło kilka miesięcy później popyt na nieruchomości mieszkaniowe. Nowe przepisy utrudniły dostęp do kredytów hipotecznych w walutach zagranicznych, a także zmieniły sposób liczenia przez banki zdolności kredytowej. Od tej chwili, niezależnie od terminu, na jaki kredyt hipoteczny miał być udzielony, banki określały zdolność kredytową tak, jakby był on zaciągany na 25 lat. Wprowadzone przepisy spowodowały spadek indeksu cen mieszkań. Można stwierdzić, że sytuacja na rynku kredytowym miała bardzo istotny wpływ na dynamikę zmian cen na rynku nieruchomości. W okresie pięcioletniej przeceny mieszkań widać momenty jej nasilenia, zwłaszcza kiedy znacznie spadała dostępność do finansowania hipotecznego. Od końca roku 2012 do dziś zdolność kredytowa i ceny nieruchomości rosną, co widać na rysunku 2.

\section{Metoda badawcza}

Stosując procedurę Engle'a-Grangera, mamy możliwość „nakreślenia” obrazu kointegracji zgodnego z założoną na wstepie teorią ekonomiczną (Charemza, 1997). Procedura ta ukazuje badaną zależność w postaci jednego równania regresji

$$
\ln Y_{t}=\beta \cdot \ln X_{t}+c+\xi_{t},
$$

które wyraża tzw. długookresową relację równowagi pomiędzy zmiennymi $\mathrm{X}$ i $\mathrm{Y}$. Zaprezentowany $w$ części empirycznej model jest w pierwszej części przykładem zastosowania procedury Engle'a-Grangera w modelowaniu kointegracji, które składa się z następujących etapów (Enders, 2003):

1. Zdefiniowanie zmiennych (jako zależna i niezależną na podstawie teorii ekonomicznej).

2. Badanie stacjonarności zmiennych $X_{t}$ i $Y_{t}$, dla których zbudowana jest relacja: $\ln Y_{t}=\beta \cdot \ln X_{t}+c+\xi_{t}$ (obie zmienne są zintegrowane $\mathrm{w}$ stopniu pierwszym w najczęściej spotykanym przypadku). 
3. Oszacowanie relacji $\ln Y_{t}=\beta \cdot \ln X_{t}+c+\xi_{t}$ metodą najmniejszych kwadratów.

4. Określenie stacjonarności wektora reszt $e_{t}$ na poziomach dla powstałej wcześniej relacji. Stacjonarność e $e_{t}$ wskazuje na istnienie wektora kointegracji, który opisuje długookresową zależność pomiędzy zmiennymi $\mathrm{X}_{\mathrm{t}} \mathrm{i} \mathrm{Y}_{\mathrm{t}}$. Poprawność związku $\ln Y_{t}=\beta \cdot \ln X_{t}+c+\xi_{t}$ stwarza możliwość budowy krótkookresowego modelu $\mathrm{z}$ mechanizmem korekty błędem ECM o postaci: $\Delta \ln Y_{t}=\alpha \cdot \Delta \ln X_{t}-\gamma \cdot \xi_{t-1}+c$ Podstawy metodologiczne procedury Engle'a-Grangera ograniczają badacza do możliwości określenia co najwyżej jednego wektora kointegracji (Gajda, 2004). Wyznaczony w ten sposób wektor kointegrujący może okazać się tylko jednym z możliwych takich wektorów.

\section{Badanie zależności poziomu cen nieruchomości od zdolności kredytowej}

Przedstawione na rysunku 2 dane to szeregi czasowe, które od roku 2009 mają częstotliwość miesięczną. Indeksy cen nieruchomości $\left(\mathrm{ICN}_{\mathrm{t}}{ }^{1}\right)$ oraz zdolności kredytowej $\left(\mathrm{IZK}_{\mathrm{t}}^{2}\right)$ zostały opracowane przez Lion's Bank na podstawie danych z banków udzielających kredytów hipotecznych oraz spółek Home Broker i Open Finance. Wartości indeksów dla początkowego zakresu próby (szczególnie ostatnie miesiące roku 2008) mają charakter poglądowy ze względu na nieregularną częstotliwość.

Rysunek 2. Indeksy cen nieruchomości oraz zdolności kredytowej w latach 2008-2014

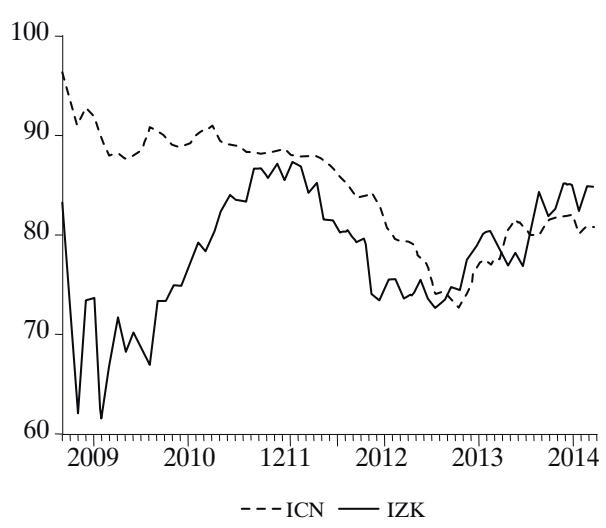

Źródło: opracowanie własne w programie Eviews.
Wstępna ocena wykresu w okresie wrzesień 2008-kwiecień 2014 pozwala dostrzec znaczną rozbieżność badanych indeksów w okresie ogólnoświatowego kryzysu i jednocześnie wspólną trajektorię szeregów czasowych dla okresu wrzesień 2008-kwiecień 2014. Wytrącenie układu z równowagi w latach 2008-2010 było na tyle silne, że spowodowało zupełne odwrócenie kierunku zależności opartej na teorii ekonomicznej pomiędzy $\mathrm{ICN}_{\mathrm{t}}$ a IZK $\mathrm{IZ}_{\mathrm{t}}$. Od ostatnich miesięcy roku 2010 do chwili bieżącej zaobserwować można występowanie dodatniej zależności pomiędzy badanymi zmiennymi. Wykres szeregów czasowych sugeruje zależność z opóźnieniem, co wydaje się uzasadnione w kontekście specyfiki testowanej zależności.

Ze względu na wspomnianą wcześniej nieregularną częstotliwość badanych indeksów w początkowym zakresie próby połączoną z załamaniem rynku nieruchomości w okresie globalnego kryzysu w badaniu autor skoncentruje się na przedziale czasu od września 2010 do kwietnia 2014.

\subsection{Badanie stacjonarności szeregów czasowych ICN $_{\mathbf{t}}$ i IZK}

Badanie stopnia integracji szeregów czasowych zostało przeprowadzone na podstawie testu Dickey-Fullera oraz pomocniczo funkcji autokorelacji (Majsterek, 2014) w programie Eviews. Oba szeregi wykazują niestacjonarność na poziomach i są zintegrowane w stopniu pierwszym.

Szereg czasowy indeksu cen nieruchomości ICN $\mathrm{I}_{\mathrm{t}}$ jest niestacjonarny na pozio-

Rysunek 3. Szereg czasowy ICN w okresie 2010.09-2014.04

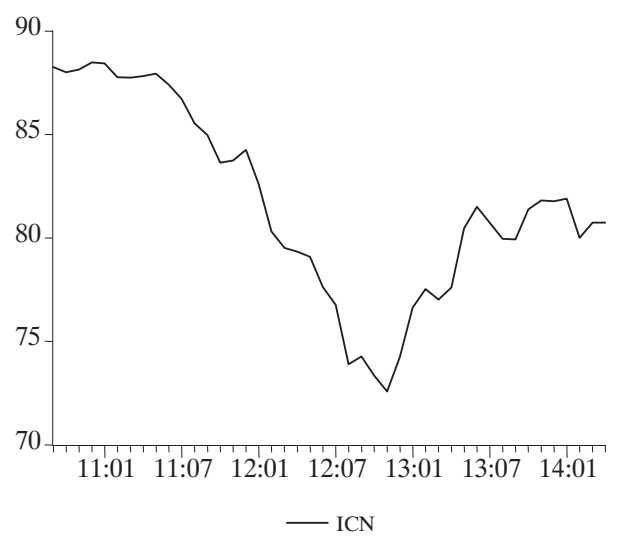

Źródło: opracowanie własne w programie Eviews. 
Tabela 1. Test ADF na poziomach dla szeregu ICN ${ }_{t}$ w okresie wrzesień 2010-kwiecień 2014

\begin{tabular}{|c|c|c|c|}
\hline \multirow[t]{3}{*}{ ADF Test Statistic } & \multirow{3}{*}{-1.537272} & $1 \%$ Critical Value* & -3.5930 \\
\hline & & $5 \%$ Critical Value & -2.9320 \\
\hline & & $10 \%$ Critical Value & -2.6039 \\
\hline
\end{tabular}

Źródło: opracowanie własne w programie Eviews.

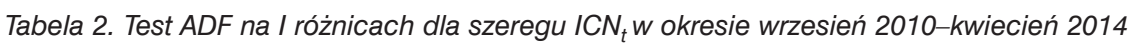

\begin{tabular}{|c|c|c|c|}
\hline \multirow{3}{*}{ ADF Test Statistic } & \multirow{3}{*}{-4.040223} & $1 \%$ Critical Value* & -3.5973 \\
\hline & & $5 \%$ Critical Value & -2.9339 \\
\hline & & $10 \%$ Critical Value & -2.6048 \\
\hline
\end{tabular}

Źródło: opracowanie własne w programie Eviews.

mach. Świadczy o tym wartość rozszerzonego testu Dickey-Fullera ADF $(-1,5372)$, która przekracza znacznie stablicowane wartości krytyczne dla przyjętych poziomów istotności (tabela 1).

Szereg czasowy $\mathrm{ICN}_{\mathrm{t}}$ należy uznać za zintegrowany w stopniu pierwszym, ponieważ wartość testu ADF $(-4,0402)$ jest wyraźnie mniejsza od wartości krytycznych (tabela 2). Do identycznych wniosków prowadzi również analiza funkcji autokorelacji dla poziomów i pierwszych różnic badanego szeregu czasowego. Dla poziomów szeregu $\mathrm{ICN}_{\mathrm{t}}$ funkcja autokorelacji przybiera kształt sinusoidalny, natomiast dla pierwszych przyrostów jest to funkcja wyraźnie gasnąca.

Szereg czasowy złożony z indeksów zdolności kredytowej IZK charakteryzuje się podobnym przebiegiem w czasie do szeregu ICN w badanym okresie. Badanie stopnia zintegrowania zostało przeprowadzone poniżej w oparciu o analogiczną metodykę.

Badanie przeprowadzone dla poziomów szeregu IZK $\mathrm{I}_{\mathrm{t}}$ potwierdza jego niestacjonarność. Wartość testu ADF $(-1,4753)$ nie pozwala odrzucić hipotezy zerowej
Rysunek 4. Szereg czasowy IZK w okresie wrzesień 2010-kwiecień 2014

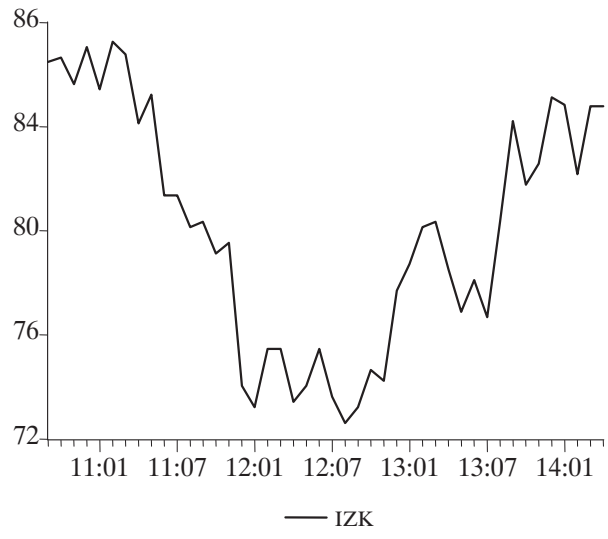

Źródło: opracowanie własne w programie Eviews.

o występowaniu pierwiastka jednostkowego (tabela 3).

Szereg czasowy IZK $\mathrm{K}_{\mathrm{t}}$ także należy uznać za zintegrowany $w$ stopniu pierwszym w analizowanym okresie na podstawie rozszerzonego testu Dickey-Fullera (tabela 4).

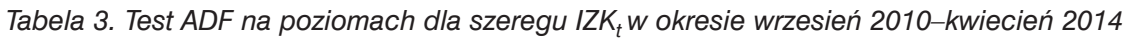

\begin{tabular}{|l|c|c|c|}
\hline ADF Test Statistic & -1.475296 & $1 \%$ Critical Value* & -3.5930 \\
\cline { 3 - 4 } & & $5 \%$ Critical Value & -2.9320 \\
\cline { 3 - 4 } & $10 \%$ Critical Value & -2.6039 \\
\hline
\end{tabular}

Źródło: opracowanie własne w programie Eviews 
Tabela 4. Test ADF na I różnicach dla szeregu IZK w okresie wrzesień 2010-kwiecień 2014

\begin{tabular}{|c|c|c|c|}
\hline \multirow[t]{3}{*}{ ADF Test Statistic } & \multirow[t]{3}{*}{-5.162493} & $1 \%$ Critical Value* & -3.5973 \\
\hline & & $5 \%$ Critical Value & -2.9339 \\
\hline & & $10 \%$ Critical Value & -2.6048 \\
\hline
\end{tabular}

Źródło: opracowanie własne w programie Eviews.

Zintegrowanie obu szeregów w stopniu pierwszym w kontekście przywołanego wcześniej wykresu i teorii ekonomicznej skłoniła autora do weryfikacji tezy o istnieniu relacji kointegrującej. Dalsza analiza zostanie oparta na procedurze poszukiwania relacji długookresowej według podejścia Engle'a-Grangera i Johansena.

\subsection{Budowa relacji długookresowej pomiędzy zmiennymi $\operatorname{ICN}_{\mathrm{t}}$ i $\mathrm{IZK}_{\mathrm{t}}$}

Estymacja modelu podejrzanego o opisywanie równowagi długookresowej została przeprowadzona w programie Eviews. Ze względu na specyfikę danych zmienna egzogeniczna została opóźniona w czasie.

Rysunek 5. Indeks cen nieruchomości oraz indeks zdolności kredytowej opóźniony o 1 miesiąc

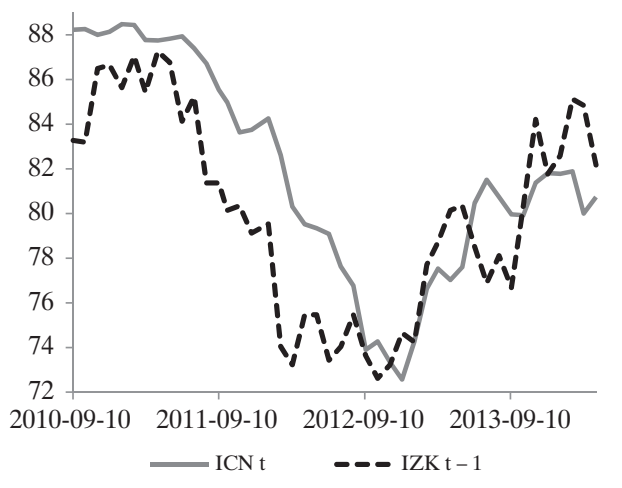

Źródło: opracowanie własne w programie Eviews.

$\mathrm{Na}$ etapie testowania różnych postaci modelu relacji długookresowej okazało się, że optymalnym opóźnieniem dla zmiennej $\mathrm{IZK}_{\mathrm{t}}$ jest 1 miesiąc. Oznacza to, że po 1 miesiącu od zmiany wartości $I_{\mathrm{Z}}$ ujawnia się efekt odpowiedniej korekty wartości $\mathrm{ICN}_{\mathrm{t}}$. Modele budowane dla opóźnień zarówno większych wykazywały gorsze własności statystyczne (mniejsze dopasowanie do danych empirycznych, mniejsze wartości statystyki t-Studenta dla parametrów modelu itd.). Wydaje się, że oczekiwanie jednoczesnego oddziaływania zmian indeksu zdolności kredytowej $\mathrm{IZK}_{\mathrm{t}}$ na indeks cen nieruchomości $\mathrm{ICN}_{\mathrm{t}}$ jest mało realistyczne. Rynek nieruchomości wymaga czasu, aby zareagować na zmiany dotyczące jego strony popytowej. Indeks zdolności kredytowej jest niepodważalnie istotnym czynnikiem kreującym popyt na mieszkania, jednak jego oddziaływanie zostaje „odczytane przez rynek” ze średnio 1-miesięcznym opóźnieniem. Jest to dość szybka reakcja, ale jednak z opóźnieniem.

Zbudowany model (tabela 5) wyróżnia się dość wysokim dopasowaniem do danych empirycznych. Relację potencjalnie opisującą zależność długookresową można zapisać jako:

$$
\mathrm{ICN}_{\mathrm{t}}=0,667 \mathrm{IZK}_{\mathrm{t}-1}+35,931-0,173 \mathrm{t} .
$$

Wzrost indeksu zdolności kredytowej $\mathrm{IZK}_{\mathrm{t}}$ o jeden punkt procentowy w okresie minionym t-1 (tj. miesiąc wcześniej) powoduje zatem przeciętnie wzrost indeksu cen nieruchomości $\mathrm{ICN}_{\mathrm{t}}$ o 0,667 punktu procentowego przy założeniu ceteris paribus. Zbudowany model (tabela 5) wyróżnia się dość wysokim dopasowaniem do danych empirycznych. Na podstawie wskazania skorygowanego współczynnika determinacji (Adjusted R-squared $=0.81$ ) można stwierdzić, że ponad $81 \%$ zmienności indeksu cen nieruchomości $\left(\mathrm{ICN}_{\mathrm{t}}\right)$ zostało wyjaśnione zmiennością indeksu zdolności kredytowej $\left(\mathrm{IZK}_{\mathrm{t}}\right)$ i zmienną obrazującą trend deterministyczny (Borkowski, 2007).

Kolejnym etapem badania stanie się weryfikacja zbudowanej wcześniej relacji długookresowej za pomocą testu stacjonarności zakłóceń. Zgodnie $\mathrm{z}$ teorią testowania kointegracji $\mathrm{w}$ ramach procedury Engle'a-Grangera poprawna relacja długookresowa powinna generować stacjonarne na poziomach składniki resztowe (Maddala, 2006). Jest to dowodem istnienia liniowej kombinacji zmiennych niestacjonarnych na 
Dependent Variable: ICN

Method: LeastSquares

Date: 05/10/16 Time: 14:44

Sample: 2010M09 2014M04

Included observations: 44

\begin{tabular}{|l|c|c|c|c|}
\hline \multicolumn{1}{|c|}{ Variable } & Coefficient & \multicolumn{1}{c|}{ Std. Error } & t-Statistic & Prob. \\
\hline \multicolumn{1}{|c|}{ IZK(-1) } & 0.667301 & 0.072611 & 9.190123 & 0.0000 \\
\hline $\mathrm{C}$ & 35.93121 & 6.285064 & 5.716919 & 0.0000 \\
\hline $\mathrm{T}$ & -0.172769 & 0.025951 & -6.657564 & 0.0000 \\
\hline R-squared & 0.823165 & Mean dependent var & 81.80936 \\
\hline Adjusted R-squared & 0.814538 & S.D. dependent var & 4.784893 \\
\hline S.E. of regression & 2.060626 & Akaike info criterion & 4.349643 \\
\hline Sum squaredresid & 174.0934 & Schwarz criterion & 4.471292 \\
\hline Log likelihood & -92.69215 & Hannan-Quinn criter. & 4.394756 \\
\hline F-statistic & 95.42699 & Durbin-Watson stat & 0.602274 \\
\hline Prob(F-statistic) & 0.000000 & \multicolumn{3}{|l}{} \\
\hline
\end{tabular}

Źródło: opracowanie własne w programie Eviews.

poziomach, które reprezentuje wektor kointegrujący zgodny z teorią ekonomiczną.

\subsection{Badanie stacjonarności składnika resztowego relacji długookresowej}

Badanie stopnia integracji zakłóceń powstałych dla relacji podejrzanej o długookresowość wykonano za pomocą rozszerzonego testu pierwiastka jednostkowego Dickey-Fullera oraz funkcji autokorelacji. Weryfikacja stacjonarności szeregu składnika resztowego na poziomach jest szczególnie istotnym punktem całej procedury Engle'a-Grangera, ponieważ pozwala rozstrzygnąć kwestię istnienia relacji długookresowej (Syczewska, 1999). W przy- padku stwierdzenia niestacjonarności reszt modelu relacji długookresowej okazuje się ona całkowicie nieprawdziwa.

Tabela 6 wskazuje na stacjonarność zakłóceń generowanych przez zbudowany model. Można zatem potwierdzić tezę, że związek pomiędzy indeksem zdolności kredytowej IZK, oraz indeksem cen nieruchomości $\mathrm{ICN}_{\mathrm{t}}$ jest $\mathrm{w}$ istocie zależnością długookresową. Zmienne poddane badaniu $\mathrm{ICN}_{\mathrm{t}}$ i IZK $\mathrm{t}_{\mathrm{t}}$ są skointegrowane, czyli pomimo iż mogą podlegać krótkookresowym fluktuacjom, to jednak pozostają również w stanie długookresowej równowagi i poruszają się po wspólnych trajektoriach długookresowych. W tej sytuacji parametr modelu

Tabela 6. Test ADF na poziomach dla składnika resztowego relacji długookresowej

Null Hypothesis: RESZTY has a unit root

Exogenous: None

Lag Length: 0 (Automatic - based on SIC, maxlag =9)

\begin{tabular}{|l|c|c|}
\hline & t-Statistic & Prob.* $^{*}$ \\
\hline Augmented Dickey-Fuller test statistic & -2.706089 & 0.0080 \\
\hline Test criticalvalues: $\quad 1 \%$ level & -2.619851 & \\
$5 \%$ level & -1.948686 & \\
$10 \%$ level & -1.612036 & \\
\hline \multicolumn{2}{|c|}{ MacKinnon (1996) one-sided p-values. } & \\
\hline
\end{tabular}

Źródło: opracowanie własne w programie Eviews. 
długookresowego równy 0.667 można interpretować jako elastyczność długookresową (tabela 5). Alternatywą procedury Engle'a-Grangera dla modelowania niestacjonarnych szeregów czasowych są modele VAR wraz z testem kointegracji Johansena.

\subsection{Budowa modelu VAR pomiędzy zmiennymi ICN $_{\mathrm{t}}$ i IZK $_{\mathrm{t}}$}

Model VAR został zbudowany dla 1 opóźnienia. Testowanie wyższych opóźnień wykazało całkowity brak istotności statystycznej współczynników przy zmiennych opóźnionych o więcej niż 1 okres pomiarowy. Podobnie nieistotna statystycznie okazała się wartość stała i trend. Oszacowania parametrów modelu VAR są zgodne $\mathrm{z}$ teorią ekonomiczną. Na uwagę zasługuje bardzo silny wpływ indeksu zmian cen nieruchomości ICN z poprzedniego miesiąca na swoją wartość bieżącą.

Zapis analityczny zbudowanego modelu VAR przedstawia się następująco:

$$
\begin{aligned}
& \mathrm{ICN}_{\mathrm{t}}=0,827 * \mathrm{ICN}_{(\mathrm{t}-1)}+0,175 * \mathrm{IZK}_{(\mathrm{t}-1)} \\
& \mathrm{IZK}_{\mathrm{t}}=0,017 * \mathrm{ICN}_{(\mathrm{t}-1)}+0,982 * \mathrm{IZK}_{(\mathrm{t}-1)}
\end{aligned}
$$

Pierwsze równanie modelu VAR jest zgodne z założeniami teorii ekonomicznej (tj. ICN zależy od zmian cen nieruchomości oraz od zmian zdolności kredytowej IZK w poprzednim miesiącu). Równanie drugie natomiast wydaje się sprzeczne $\mathrm{z}$ teorią

Tabela 7. Model VAR dla zmiennych ICN $i I Z K_{t}$

Vector Autoregression Estimates

Date: 05/10/16 Time: 10:53

Sample: 2010M09 2014M04

Included observations: 44

Standard errors in ( ) \& t-statistics in [ ]

\begin{tabular}{|l|c|c|}
\hline \multirow{2}{*}{ ICN(-1) } & ICN & IZK \\
\cline { 2 - 3 } & 0.826582 & 0.017442 \\
\cline { 2 - 3 } & $(0.04075)$ & $(0.08914)$ \\
\hline \multirow{2}{*}{ IZK(-1) } & 0.175419 & {$[0.19567]$} \\
\cline { 2 - 3 } & $(0.04176)$ & 0.982276 \\
\cline { 2 - 3 } & {$[4.20050]$} & {$[0.09136)$} \\
\hline R-squared & 0.962724 & 0.808747 \\
\hline Adj. R-squared & 0.961837 & 0.804193 \\
\hline Sum sq. resids & 36.69769 & 175.6247 \\
\hline S.E. equation & 0.934748 & 2.044881 \\
\hline F-statistic & 1084.740 & 177.6042 \\
\hline Log likelihood & -58.44083 & -92.88481 \\
\hline Akaike AIC & 2.747310 & 4.312946 \\
\hline Schwarz SC & 2.828410 & 4.394045 \\
\hline Mean dependent & 81.80936 & 80.04843 \\
\hline S.D. dependent & 4.784893 & 4.621194 \\
\hline Determinant resid covariance (dof adj.) & 3.618250 \\
\hline Determinant residcovariance & & 3.296794 \\
\hline Log likelihood & & -151.1115 \\
\hline Akaikeinformationcriterion & & 7.050523 \\
\hline Schwarz criterion & & 7.212722 \\
\hline
\end{tabular}

Źródło: opracowanie własne w programie Eviews. 
ekonomiczną. Badane zmienne są niestecjonarne na poziomach, ale zintegrowane na pierwszych różnicach, stąd zbudowano również model VEC dla opóźnień od -1 do 1. Model VEC posiada interpretowalne parametry dostosowania, jednak w wielu przypadkach dość duże błędy standardowe oszacowań elastyczności krótkookresowych. Górna część tabeli 8 pozwala odczytać skalar kointegracji o wartości 1.014. Warto zaznaczyć, że wartość 1.014 posiada bardzo mały błąd standardowy oszacowania 0.0098, a w konsekwencji bezwzględnie wysoką statystykę t-Studenta -103.453 .
$\mathrm{Na}$ tej podstawie można stwierdzić, że oszacowanie długookresowej zależności pomiędzy ICN oraz IZK jest tu istotne statystycznie.

Dodatkowo testowanie liczby wektorów kointegracji zostało przeprowadzone na podstawie testu Johansena (Kusideł, 2000):

$\mathrm{Z}$ danych zawartych $\mathrm{w}$ tabeli 9 wynika, że występuje tylko jeden wektor kointegracji, a więc w długim okresie poprawna jest wyłącznie relacja zgodna z teorią ekonomiczną. W programie Eviews została oszacowana wartość parametru relacji długookresowej o wartości 1,014 (tabela 8).

Tabela 8. Model VEC dla zmiennych ICNt i IZKt

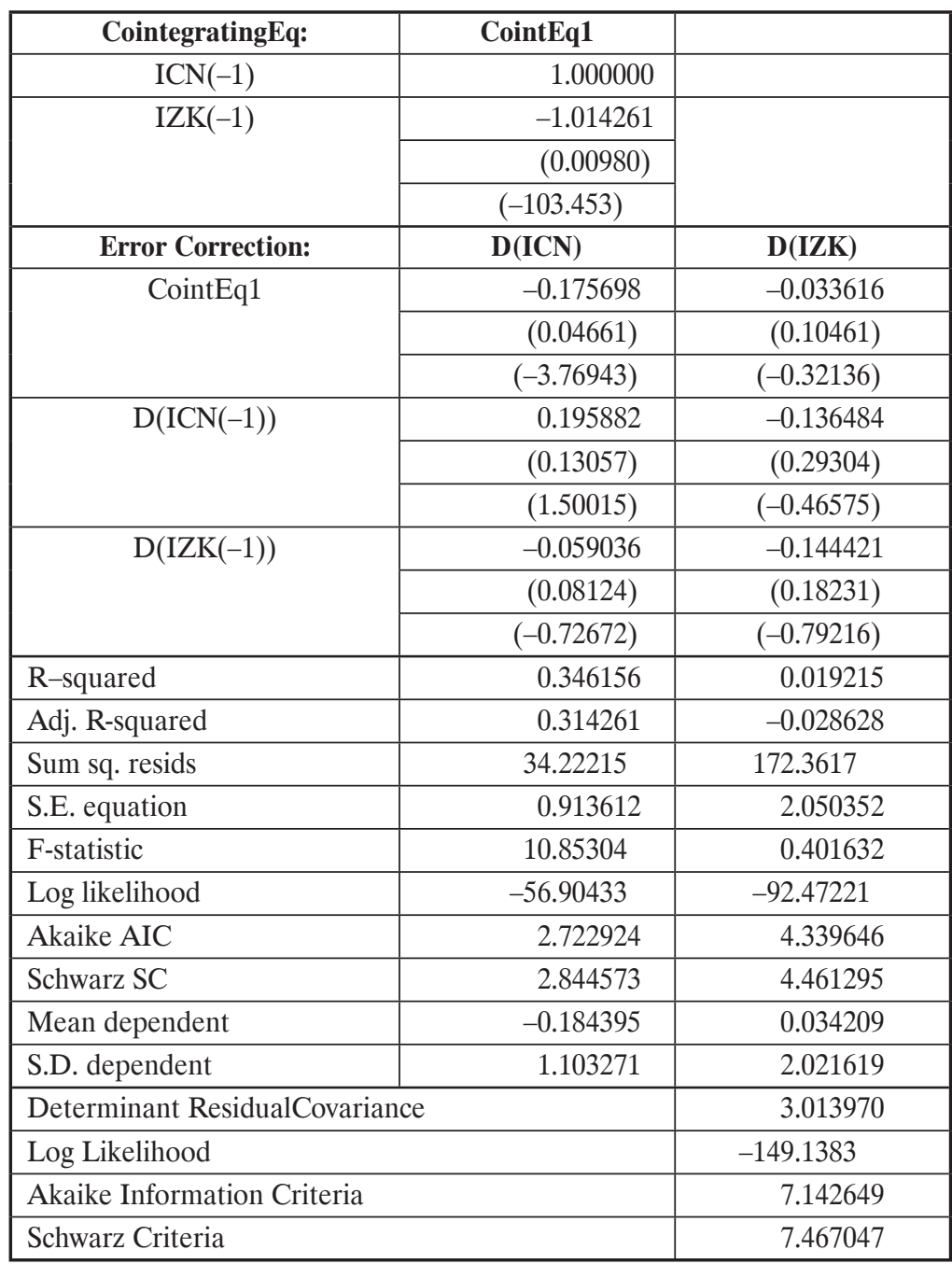

Źródło: opracowanie własne w programie Eviews. 
Tabela 9. Test kointegracji Johansena dla zmiennych ICN $i$ IZK

Date: 05/10/16 Time: 16:03

Sample: 2010M09 2014M04

Included observations: 44

Trend assumption: No deterministic trend

Series: ICN IZK

Lags interval (in first differences): 1 to 1

Unrestricted Cointegration Rank Test (Trace)

\begin{tabular}{|c|c|c|c|c|}
\hline Hypothesized & & Trace & 0.05 & \\
\hline No. of CE(s) & Eigenvalue & Statistic & Critical Value & Prob.** $^{* *}$ \\
\hline None $^{*}$ & 0.257429 & 13.09698 & 12.32090 & 0.0370 \\
\hline At most 1 & $2.22 \mathrm{E}-05$ & 0.000975 & 4.129906 & 0.9814 \\
\hline
\end{tabular}

Trace test indicates 1 cointegratingeqn(s) at the 0.05 level

* denotes rejection of the hypothesis at the 0.05 level

** MacKinnon-Haug-Michelis (1999) p-values

Źródło: opracowanie własne w programie Eviews.

Jest to wynik przekraczający oszacowanie wartości współczynnika relacji długookresowej otrzymanego na podstawie procedury Engle-Grangera. Znak współczynnika jest jednak poprawny z punktu widzenia zależności rynkowych w obu procedurach.

\section{Podsumowanie}

1. Dla badanego okresu od września 2010 do kwietnia 2014 można potwierdzić tezę o występowaniu związku kointegracji dla indeksu cen nieruchomości $\left(\mathrm{ICN}_{\mathrm{t}}\right)$ oraz indeksu zdolności kredytowej $\left(\mathrm{IZK}_{\mathrm{t}}\right)$ na podstawie podejścia Engle-Grangera i Johansena.

2. Zależność obu indeksów występuje z uzasadnionym ekonomicznie opóźnieniem. W przypadku badanego rynku nieruchomości okazało się, że musi minąć miesiąc, aby zmiana dostępności kredytów spowodowała korektę cen.

3. Model VAR i związana $\mathrm{z}$ nim procedura Johansena pozwoliły określić elastyczność długookresową równą 1.014. Oznacza to, że wzrost indeksu zdolności kredytowej o jeden punkt procentowy wywołuje średnio wzrost indeksu cen nieruchomości $\mathrm{ICN}_{\mathrm{t}}$ o 1.014 punktu procentowego z opóźnieniem miesiąca.

Zatem jeśli można wierzyć szacunkom, to elastyczność długookresowa o wartości ponad 1 może wskazywać na proces sprzyjający tworzeniu się baniek spekulacyjnych na rynku nieruchomości (indeks cen rośnie szybciej niż indeks zdolności kredytowej). $\mathrm{Z}$ drugiej strony współczynnik elastyczności długookresowej dla procedury Engle-Grangera jest mniejszy od jedności. Procedura Johansena oparta na modelowaniu autowektorowym uznawana jest za narzędzie bardziej wiarygodne w badaniach empirycznych (Welfe, 2009).

\section{Przypisy}

$1 \mathrm{ICN}_{\mathrm{t}}$ - publikowany co miesiąc przez Home Broker i Open Finance indeks cen mieszkań powstający na podstawie transakcji w 16 miastach (Białymstoku, Zielonej Górze, Bielsku-Białej, Toruniu, Bydgoszczy, Krakowie, Lublinie, Gdańsku, Gdyni, Olsztynie, Katowicach, Łodzi, Poznaniu, Szczecinie, Wrocławiu i Warszawie). Indeks obliczany jest zgodnie ze wzorem:

$$
\begin{aligned}
\text { Indeks } & =C_{1}\left(\frac{l_{1}}{S_{t}}\right)+C_{2}\left(\frac{l_{2}}{S_{t}}\right)+C_{3}\left(\frac{l_{3}}{S_{t}}\right)+C_{4}\left(\frac{l_{4}}{S_{t}}\right)+ \\
& +\ldots+C_{16}\left(\frac{l_{16}}{S_{t}}\right)
\end{aligned}
$$

gdzie:

$l_{1}, l_{2}, l_{3}, l_{4}, \ldots, l_{16}$ - ilość transakcji wykonanych w każdym z miast,

$S_{t}$ - suma transakcji dokonanych we wszystkich miastach,

$C_{1}, C_{2}, C_{3}, C_{4}, \ldots, C_{16}$ - ceny jednego metra kwadratowego mieszkania w poszczególnych miastach, obliczone zgodnie ze wzorem: 
Cena $=\left(m_{1} \cdot 0,5\right)+\left(m_{2} \cdot 0,3\right)+\left(m_{3} \cdot 0,2\right)$

gdzie:

$m_{1}$ to mediana wartości jednego metra kwadratowego w ostatnim miesiacu kalendarzowym, $m_{2}$ to mediana wartości jednego metra kwadratowego w miesiącu $\left(m_{1}-1\right)$,

$m_{3}$ to mediana ceny metra kwadratowego w miesiącu $\left(m_{1}-2\right)$.

$2 \mathrm{IZK}_{\mathrm{t}}$ - indeks zbudowany na podstawie danych zawierających mediany zdolności kredytowej dla rodziny modelu $2+1 \mathrm{z}$ dochodem na poziomie 5 tys. zł netto gromadzone przez Lion's House. Kredyt na 30 lat, zakup nieruchomości w mieście o liczbie ludności 150 tys.

\section{Bibliografia}

Borkowski, B., Dudek, H. i Szczesny, W. (2007) Ekonometria, wybrane zagadnienia. Warszawa: Wydawnictwo Naukowe PWN.
Charemza, W. i Deadman, D. (1997). Nowa ekonometria. Warszawa: PWE.

Enders, W. (2003). Applied Econometric Time Series. New York: John Wiley \& Sons.

Gajda, J. (2004). Ekonometria. Warszawa: C.H. Beck.

Kusideł, E. (2000). Modele wektorowo-autoregresyjne VAR metodologia i zastosowania. Łódź: Absolwent.

Maddala, G.S. (2006). Ekonometria. Warszawa: Wydawnictwo Naukowe PWN.

Majsterek, M. (2014). Modelowanie systemów skointegrowanych. Aspekty teoretyczne. Bank $i$ Kredyt, 45(5).

Syczewska, E. (1999). Analiza relacji dtugookresowych: estymacja $i$ weryfikacja. Warszawa: Oficyna Wydawnicza SGH.

Welfe, A. (2009). Ekonometria. Warszawa: PWE. 